\title{
Acute stroke management
}

\section{The plight of Nepal}

Avinash Chandra, MD, Pravesh Rajbhandari, MS, and Basant Pant, MD, PhD

Neurology ${ }^{\circledR}$ 2019;92:e1022-e1023. doi:10.1212/WNL.0000000000007528
Correspondence

Dr. Chandra

chandraavi@gmail.com
When acute ischemic stroke presents within the time window of 3-4.5 hours, it can be treated with IV tissue plasminogen activator (tPA) with the best outcomes. ${ }^{1}$ Stroke exhibits a decreasing trend in high-income countries, e.g., stroke has decreased to the third leading cause of death or disability in the United States. Robust economy, wide coverage of health insurance, better public health education, and effective health care policies are some important factors that have helped to curb disease progression. On the other hand, the incidence of stroke exhibits an increasing trend in low-income countries like Nepal. ${ }^{2}$ Due to the limited resources available, and outdated and ineffective public health policies in these nations, access to standard health care to all is nearly impossible. Stroke care units are an essential ingredient underpinning the safe implementation of stroke thrombolysis. Through this article, we have attempted to share our experience, as well as the results on acute stroke management.

Nepal is a landlocked country surrounded by some of the highest mountains in the world. According to the $\mathrm{WHO}$, more than $70 \%$ of the health expenditure comes from out-ofpocket contributions from individuals in Nepal. Changes in lifestyle, lack of education and awareness about the symptoms of stroke, high cost and paucity of thrombolytic agents, low availability of emergency services, few hospitals having neurology departments, few imaging centers with CT/MRI, only a handful of neurologists (fewer than 30 in a nation with a population of nearly 29.3 million, according to the 2017 census), chaotic traffic on the streets, and difficult and dangerous roads are some major hurdles in providing proper stroke care. ${ }^{3}$ Administration of IV tPA has been licensed in Nepal for thrombolysis in selected patients with acute ischemic stroke only recently. The use of tPA is still low (but with increasing trends) across Nepal. We performed an observational study on an institutional basis regarding IV tPA usage in acute ischemic stroke. This institutional experience statement provides a review of the evidence for and implementation of tPA in acute ischemic stroke with specific reference to the Nepalese health care system. In our institution, more than 300 patients were admitted in the inpatient ward with the diagnosis of ischemic stroke (chief complaints of weakness of either side of body or slurring of speech or dizziness and vertigo with difficulty in balancing body) (from early 2016 to February 2018), among whom $30 \%$ appeared within 24 hours of stroke onset but more than 4.5 hours (table). Administration of tPA was based on international inclusion and exclusion criteria and an international dosing protocol $(0.9 \mathrm{mg} / \mathrm{kg}$ body weight with $10 \%$ of total given as bolus and the remaining over an hour). We found that a little over $5 \%$ of patients (15) were eligible for IV tPA (including a time window of 4.5 hours). Twenty percent of patients with stroke had TIA or rapidly improving stroke-like symptoms anytime in their lives. About $15 \%$ of patients in our total stroke population were not even aware if they had a stroke. This shows the importance of establishing strategies for public education of stroke. ${ }^{4}$ The NIH Stroke Scale (NIHSS) scores of our patients with stroke ranged from 1 to 22. Among tPAeligible candidates, the NIHSS scores ranged from 6 to 18 (interquartile range of 8). Notably, many among them had important neurologic deficits like aphasia and dysarthria (more than 10 patients) despite their total NIHSS scores being on the lower side (as low as 6). The NIHSS scores were calculated 24 hours post-IV tPA administration. Post-IV tPA 
Table Demographics and clinical characteristics

\begin{tabular}{ll}
\hline Sex, M/F, n (\%) & Values \\
\hline Age, y, min/max; mean (SD) & $223(66.2) / 114(33.8)$ \\
\hline NIHSS, min/max & $15 / 97 ; 60.8(15.4)$ \\
\hline Mortality during hospital stay, total (\%) & $22 / 1$ \\
\hline
\end{tabular}

administration, there was a substantial improvement observed, seen clinically as well as in the NIHSS scores. PostIV tPA administration, NIHSS ranged from 10 to 1 (interquartile range of 2). Patients whose speech was affected exhibited a notable improvement. Hence, using tPA even in those with low NIHSS scores carried a useful meaning in our setting. ${ }^{5}$ The door to needle time was impressive in our study ( 1.5 hours on average). Our institution is a nongovernmental tertiary institute in neurology. There are very few hospitals in Nepal with multiple subspecialties in medicine or surgery.

Offering tPA to eligible patients has not been an easy task in situations where patients must pay for the treatment out of their own pocket. Here we describe how we have been successful in administering tPA until now. Our institution has played a key role in passing the proposal in the Department of Drug Administrations. Our institute has acquired MRI (0.3T) and CT scan (32 slice) machines before the initiation of thrombolysis in ischemic stroke. Some of the staff were trained in performing thrombolysis with the help of international organizations, video tutorials, and simulators. The staffs were required to undergo different tests with clinical scenarios before being able to perform thrombolysis. Coping with the high cost of tPA has remained a major challenge. We have adopted as much as possible to reduce the cost of

Figure Flow chart

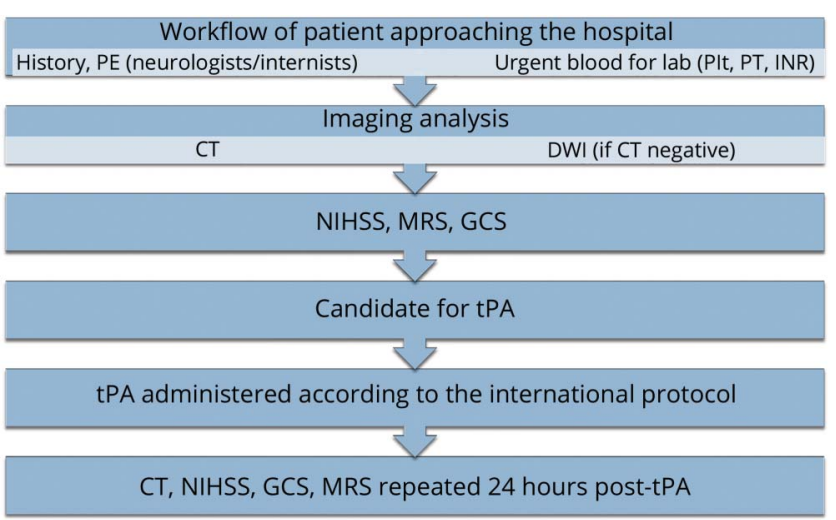

DWI = diffusion-weighted imaging; GCS = Glasgow Coma Scale; INR = international normalized ratio; MRS = magnetic resonance spectroscopy; $\mathrm{NIHSS}=\mathrm{NIH}$ Stroke Scale; $\mathrm{PT}$ = prothrombin time; $\mathrm{tPA}=$ tissue plasminogen activator. thrombolysis including the mode of imaging and laboratory investigations.

For those patients who appear within the time window $(<3.5$ hours of onset), we perform CT. If the CT appears normal, a diffusion-weighted imaging (DWI) sequence of MRI is performed within the same time. We perform only the DWI sequence (not the T1- or T2-weighted or fluid-attenuated inversion recovery images of MRI) for the sake of saving cost and time for tPA. The DWI sequence costs only one-third of full sequences of MRI. At the same time as the imaging is conducted, we also send blood for the laboratory workup report, mainly for platelet count, prothrombin time, and international normalized ratio. By then, the neurologist and internist have already finished their history-taking and necessary clinical examinations to rule out stroke mimics and have also obtained the patient's (or their immediate relatives') consent for IV tPA administration. tPA is then administered and CT images are obtained 24 hours post tPA to rule out any other complications. The flowchart is diagrammatically represented in the figure. The purpose of writing this report is mainly to bring the attention of the world to the issues that we face and the solutions that we have devised to reduce the cost but provide better stroke care. Through this article, we have attempted to highlight the issues that low-income nations face. In fact, there have been many hurdles in implementing proper stroke care. The lack of public health education is one of the major hurdles, besides others. However, despite all these hurdles, thrombolysis is already implemented and gaining momentum in different centers. We have been able to save some lives and prevent disabilities due to stroke. We are also heading towards implementing thrombectomy.

\section{Author contributions}

Avinash Chandra: study concept, analysis, and design. Basant Pant: critical revision of the manuscript for important intellectual content. Pravesh Rajbhandari: acquisition and interpretation of data.

\section{Study funding}

No targeted funding reported.

\section{Disclosure}

The authors report no disclosures relevant to the manuscript. Go to Neurology.org/ $\mathrm{N}$ for full disclosures.

\section{References}

1. Asaithambi G, Tong X, George MG, et al. Acute stroke reperfusion therapy trends in the expanded treatment window era. J Stroke Cerebrovasc Dis 2014;23:2316-2321.

2. Kaul S, Bandaru VC, Suvarna A, Boddu DB. Stroke burden and risk factors in developing countries with special reference to India. J Indian Med Assoc 2009;107: 367-370.

3. Nagendra CV, Kumar TSS, Bohra V, Wilben V, Karan V, Huded V. Factors affecting the effective management of acute stroke: a prospective observational study. Indian J Crit Care Med 2018;22:138-143.

4. Fogle CC, Oser CS, Troutman TP, et al. Public education strategies to increase awareness of stroke warning signs and the need to call 911. J Public Health Manag Pract 2008; 14:e17-22.

5. Martin-Schild S, Albright KC, Tanksley J, et al. Zero on the NIHSS does not equal the absence of stroke. Ann Emerg Med 2011;57:42-45. 


\title{
Neurology
}

\author{
Acute stroke management: The plight of Nepal \\ Avinash Chandra, Pravesh Rajbhandari and Basant Pant \\ Neurology 2019;92;1022-1023 \\ DOI 10.1212/WNL.0000000000007528
}

This information is current as of May 20, 2019

\section{Updated Information \& Services}

\section{References}

Subspecialty Collections

Permissions \& Licensing

Reprints including high resolution figures, can be found at: http://n.neurology.org/content/92/21/1022.full

This article cites 5 articles, 0 of which you can access for free at: http://n.neurology.org/content/92/21/1022.full\#ref-list-1

This article, along with others on similar topics, appears in the following collection(s):

All Cerebrovascular disease/Stroke

http://n.neurology.org/cgi/collection/all_cerebrovascular_disease_strok

Embolism

http://n.neurology.org/cgi/collection/embolism

Infarction

http://n.neurology.org/cgi/collection/infarction

Stroke in young adults

http://n.neurology.org/cgi/collection/stroke_in_young_adults

Stroke prevention

http://n.neurology.org/cgi/collection/stroke_prevention

Information about reproducing this article in parts (figures,tables) or in its entirety can be found online at:

http://www.neurology.org/about/about_the_journal\#permissions

Information about ordering reprints can be found online:

http://n.neurology.org/subscribers/advertise

Neurology ${ }^{\circledR}$ is the official journal of the American Academy of Neurology. Published continuously since 1951, it is now a weekly with 48 issues per year. Copyright (O 2019 American Academy of Neurology. All rights reserved. Print ISSN: 0028-3878. Online ISSN: 1526-632X.

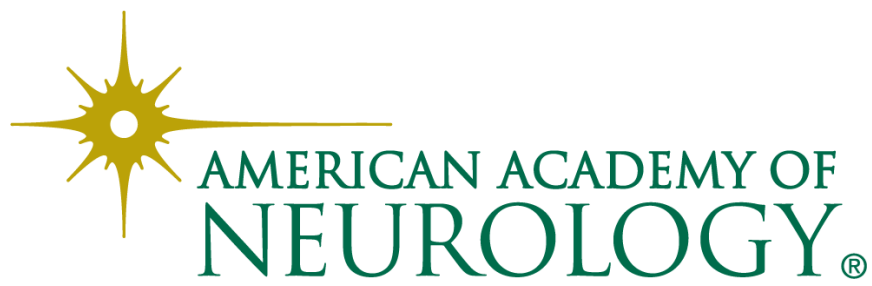

